\title{
BILINGUALISM AND PERSONALITY GROUP DYNAMICS: A NIGERIAN (IGBANKE) CASE STUDY
}

\author{
by \\ Dr. Nduka Okoh \\ Department of Adult Education \& Extra-Mural Studies \\ University of Benin, Nigeria.
}

\section{ABSTRACT}

In socio-psycho-linguistics; the phenomenon of bilingualism is well known as a significant variable posing cultural, political, economic and educational problems at both personal and group levels. This paper addresses itself specifically to some of the socio-psychological problems experienced by a particular border-bilingual community in Nigeria - Igbanke in Bendel State of Nigeria. The historical antecedents as well as the current existential situation of "cultural ambivalence" and "political instrumentalism" of the Igbanke people are briefly examined and analysed. It was also noted that this state of affairs is fairly common among border communities in Bendel State in particular and in Nigeria generally, and that further extensive as well as in-depth studies in this field would be useful for both research and practical purposes.

\section{INTRODUCTION:}

Human language may be described as the communication system that distinguishes man uniquely from other living species, 'serving the dual purpose of inter-personal and intra-personal communication in the form of thought. Language of course, is much more than a means of communication. If that were its only function, according to Lord Chalfont (1973), an artificial interlingua like Esperanto 'would be of more value than Italian, and Welsh would have no more importance than the noises made by dolphines or ducks'. Language to him is a 'treasury of shared experience and racial memory, the raw rnaterial of the literary and cultural heritage of a people'. Whatever its functions, however, human language is basically a social inheritance and, therefore, a function of learning and personality dynamics.

\section{BIINGUALISM:}

Turning to the term, "bilingualism" itself, one finds that sometimes it is used to describe a situation where two languages are spoken in a community but in which most of the people only speak one or other of the two languages, and are therefore actually monolingual. Auchamp (1926), for example, defined bil- 
ingualism as a condition 'in which two languages exist side by side in a country, each spoken by one national group, representing a fairly large proportion of people'. This may be loosely termed "political bilingualism" or "parallel bilingualism" as is the case in countries like Belgium, Canada and South Africa, where equal official recognition is given to two languages, at least constitutionally.

Increasingly, however, bilingualism has been looked at, by various workers from various disciplines, more on the personal level. For example, Weinreich (1953) defined bilingualism as 'the use of two languages alternately by the same person'. this accent takes cognizance of the near universality of some form of bilingualism all over the world, and the increasing number of people in the conditions of modern day living who have to be bilingual. After the mythical fracture of the human 'primal language' at Babel (Steiner, 1972), there are said to exist between 8000 to 10,000 languages in use in the world today, and some form of bilingualism has obviously been inevitable from earliest times in almost all countries - but usually among certain necessarily restricted groups, e.g. in mixed marriages, amongst Government officials, businessmen, travellers and missionaries in foreign countries, amongst the educated elite who cultivate it for cuitural or academic usé, and amongst groups of people spanning language borders. Also, even more increasingly, greater emphasis is being placed on the degree of bilinguality, i.e. the degree of proficiency in the use of the two languages. At first the emphasis on bilingualisn was on what Bloomfield (1933) called 'native-like control of languages', and Leopold (1939) defined it as the 'ability to speak two languages equally well for all purposes of life'. This may be termed "equibiligualism" which Mahherbe (1946) described as "unmitigated nonsense and an unapproachable ideal of perfectability'.

The contemporary viewpoint is underlined by Pattison (1966) who affirms that anybody who learns a second language becomes to some degree bilingual, but the degree becomes significant only when he habitually uses the two languages. He talked of 'the scale of bilingualism which ascends from a few phrases of the second language through gradations of inequality between the two languages to command of both, though usually for different purposes, and concludes that the situation in which people move freely and confidently in two speech communities is so much the most interesting and important that it is wise to restrict the term "bilingualism" to it. This is in fact the general orientation adopted for this paper, and the "bilingual person" is operationally defined as "the person who is able to communicate effectively (through the medium of speech, or reading comprehension, or writing) in two languages, though not necessarily with equal mastery, at a level appropriate to his age-group" 


\section{耳耳. BILINGUALISM AND THE PROHLEM OF IDENTIFICATION}

As mentioned earlier, bilingualism may be regarded essentially more as a socio-psychological problem than a purely linguistic one. This paper examines some socio-psychological factors surrounding some bilingual situations in Nigeria. The problem of identification is paramount in any bilingual situation. In the specific case of Nigeria, personality conflict arising from culture (language) contact can be found among all Nigerians: (1) at the macro level between all ethnic groups and the foreign imposed European culture, (2) at the intermediate level in all communities (mostly border areas) where two or more indigenous cultures meet and mix, and (3) at the individual level where husband and wife/wives have different linguistic backgrounds and where the children have to be socialised in the various languages.

\section{THE IGRANKE SITUATION:}

In the acculturation process, the impact of various ethnic groups, systems and institutions impinging on each other in any given community produces conflict, cooperation and compromise, resulting in the emergence of a 'new culture'. Weiser (1937) has asserted that contact between groups may be beneficial if the differences between them are minor, but harmful to at least one if the differences are great.

Igbanke is a border community of six confederal villages situated in the eastcentral part of Bendel State. It is flanked, roughtly speaking, by Edo culture area of the west, by Esan culture area in the north and north-east, and by the Ika (Igbo) culture area in the south and southeast, and is therefore an amalgam or melting pot of many cultures and characterised by a high incidence of cultural (particularly linguistic) borrowing. Historically and initially, all the three 'languages' (Edo, Esan and Ika) were used as media of communication within the various villages which were fairly autonomous and separated from each other by forest. Over a period of time, contact between the villages increased and the Ika language gradually became dominant. This is confirmed by the fact that the vast majority of the octogenarians living in Igbanke today bear names that reflect their earlier linguistic and culture area origin (Edo, Esan and Ika), whilst most of the people below 50 years old bear Ika names. The historical connection of Ika with Igbanke, the nearness of Agbor and Mbiri to Igbanke, as well as the population of the Ika-speaking villages have contributed to Ika affecting 'the Igbanke 'language' much more profoundly than Edo or Esan. Nevertheless, in spite of Benin influence, Igbanke's political structure does not significantly reflect Benin origin - the socio-political organisation of 
all the six villages is almost the same as with Ika where the administrative system is based on the village. The different villages operate independently, each with its own traditional titled chiefs (Ndichien), who again usually hail from different quarters (Idumu) that trace their descent to a single ancestor and operate the age-grade system. (Onwuejeogwu, 1972).

Acculturation no doubt has brought certain benefits to Igbanke, e.g. richer culture, richer 'language' and 'in this over-politicised country they (Igbanke) stand a better chance of claiming affinity with any ethnic group if there is anything to be gained from such affiliation' (Moseri, 1980). For instance, up till 1895 Igbanke people were closely affiliated with Agbor with the attendant benefits, especially as at that time colonial commercial activities at Asaba made Agbor a fertile ground for economic activities as well. In 1906, however, Benin was made the administrative headquarters, and agitation for succession from Agbor led to Igbanke being incorporated into Benin Province. Igbanke people's apparent negative attitude to Ika language and people stems from both historical and political reasons: (a) the Agbor-Igbanke war of 1895, (b) the prestigious position that Edo currently enjoys in Bendel State vis $a$ vis Ika.

One of the major disadvantages and source of tension resulting from the said acculturation is that Igbanke lack both linguistic and cultural identity. Another way of looking at the matter is that bilingualism affords a mechanism of readjustment for a people caught up in a cultural dilemma. When adjustment produces negative result, the issue of identity is re-examined. For example, agitation to rejoin their 'Kith and Kin' in Agbor started around 1965 on the grounds that the relationship between Benin and Igbanke is of an unequal nature. Various other claims/reasons given for the agitation to be regrouped with Ika were: (a) imposed wrong grouping with Edo, (b) taxation without commensurate amenities from Benin, (c) linguistic differences, and (d) alleged disdainful treatment of Igbanke by Edo. Linguistically, although fieldwork findings (Moseri, 1980) indicate strongly that Igbanke speech pattern has closer relationship to Ika than to Edo or Esan, yet many Igbanke people who have been interviewed would prefer (for understandable instrument reasons) to claim closer affinity of Igbanke 'language' with Edo language rather than with Ika. It is argued (Moseri, 1980) that the very people with whom the Igbanke now claim affinity with (i.e. the Eclo) regard both the Igbanke 'language' and people as essentially Ika, as evidenced by the pejorative nickname ('Ika noriagwo' - Ika the snake-eaters) which the Edos use for Igbanke people.

Also, fieldwork findings have shown that children between 14 and 15 years of age from bilingual homes in Igbanke and who were being taught in Edo language were neither here nor there, linguistically speaking - i.e. they could neither speak Edo nor Ika proficiently. For the most part, the meaning of words in both languages is mixed up by these children (Moseri, Osazuwa, 1980). 1980). 


\section{CONCLUSHON:}

The foregoing has been a brief analytical account of a particular bilingual situation (Igbanke) in Bendel State and the problems of personal, socio-cultural and political identity posed by the fact of this bilinguality. The identity (personal, political and socio-cultural) of the Igbanke people has been determined in the main by the fluctuations of political power. So that today they are in the ambiguous position where they are regarded by themselves and by others as neither fully Edo nor fully Ika. This ambivalence strangely has increased the incidence of bilingualism in the Igbanke community.

It should be re-emphasised here that this state of affairs is by no means peculiar to Igbanke, but is in fact very widespread amongst many communities in Bendel State in particular as well as the rest of Nigeria in general. Some examples that come to mind here are the Ugbodu in Aniocha LGA where 'lukwumi' (identified by linguists and anthropologists as an ancient Yoruba dialect now extinct in Nigeria but curiously still extant Brazil) and Aniocha Igboid language dialect form are spoken; Ebu (also in Aniocha LGA) where some form of Igala is spoken alongside Aniocha-Igbo; Igbodo in Ika LGA where two dialects of the same Igbo language (Ika and Aniocha) meet; Ozarra in Orhionmwon LGA where Edo and Ika also meet; Orogun in Okpe LGA where Urhobo and same remnants of Western Igboid language meet, albeit unequally, and many others.

\section{REFERENCES}

1. Auchamp, A. J. (1926) Bilingual Education and Nationalism, with special reference to South Africa. Pretoria (248 pp.)

2. Bloomfield, L. (1933): Language. New York: Harper and Row.

3. Chalfont, Rt. Non. Lord (1973) 'Foreword' to The Welsh Language Today (ed. Stephens, M.) Llandysul: Gomer Press.

4. Fishman, J.A. et al (ed.) (1968): Language Problems of Developing Nations. New York: Wiley

5 Hornby, P. (ed) (1977) Bilingualism; psychological, social and educational implications. London: Academic Press.

6. Hymes, D. (ed.) (1964) Language and Culture in Society. New York: Harper and Row.

7. Khlieff, B.B. (1975): Ethnic Boundaries, Identity and Schooling: A Socio-Cultural Study of Welsh-English Relations. Durham: Univ. of New Hampshire.

8. Leopold, W. (1939): Speech development of a bilingual child: A linguist's record. Evanston: Chicago.

9. Macnamara, J. (1967): 'Problem of Bilingualism'. J. Sco. Issues, 23, 29-38. 
10. Malharba, E.G. (1946) The Bilingual School: A study of Bilingualism in Sourh Africa. Johannesburg:

11. Manfredi, V. (1982): 'Centre and Periphery in Ika Literacy'. JOLAN, Vol. 1, No. 1. pp. $175-195$.

12. Moseri, P. Y. (1980): Problem of Bilingualism in Igbanke. (Unpublished B.Sc. Sociology Research Project. University of Benin).

13. Nwanwene, O. (1954): Pride of Igbanke. London Pengiun

14. Okoh, N. (1980): 'Bilingualism and Divergent Thinking Among Nigerian and Welsh School Children'. J. Soc. Psych., 110, pp. $163-170$.

15. Onwuejeogwu, M.A. (1979): 'The dawn of Igbo Civilisation' Odinani Journal.

16. Osazuwa, R. (1980): Igbanke Confederation and its integrationt in Orbionmwon LGA, Bendel State, Nigeria. (Unpublished B.Sc. Sociology Research Project, University of Benin).

17. Midwest State, Nigeria (1965) Report of the Committee on Languages of Midwestern State, Benin City, 1965

18. Steiner, G. (1972): After Babel. Cambridge: Cambridge University Press. 